Ann. Biol. anim. Bioch. Biophys., I975, 15 (I), I I0-I22.

NOTF

\title{
RETENTION OF NUCLEAR BASIC PROTEIN IN RABBIT SPERMATOZOA UP TO ENTRY INTO THE VITELLUS
}

\author{
V. KOPEČNÝ and J. FULKA \\ with technical assistance of $\mathrm{V} . \mathrm{PECH}_{\mathrm{E}}$ \\ Institute of Animal Physiology and Genetics, \\ Czechoslovak Academy of Sciences, \\ Libechov (Czechoslovakia)
}

The dynamism of basic nuclear protein has been studied in mammalian male germ cells in mouse, bull and ram up to the epididymal spermatozoon stage (Monesi, 1964, 1965; GLedHrL et al., I966; LoIr, I972 $a$ and $b$ ). After natural mating in mouse, we find that arginine ${ }^{14} \mathrm{C}$-labelled nuclear protein is retained in ejaculated spermatozoa in ampublae oviducti in the close vicinity of the ovum (KopeČn' Ý, I970). However, KOPEČN ' and PAVLOK (I975), studying ova fertilized in vitro, concluded that this protein is suddenly lost during the earliest stages of male pronuclear formation. The particularly rapid disappearance of labelled nuclear protein in fertilization led us to reinvestigate the presumed resistance of similar labelling in spermatozoa of another species during independent life in the female genital tract. Rabbit seemed especially suited to this purpose because spermatozoa must spend a much longer time in the female genital tract before entering the ovum in this species than in the mouse. Some observations indicate a change in rabbit sperm chromatin during its passage through the female genital tract (CHANG, I959; OrgeBINCRIST, 1969). In addition to this, supplementary spermatozoa accumulate in considerable quantities in the perivitelline space of rabbit oocyte.

Four mature male rabbits were injected intratesticularly as described elsewhere (FunkA et al., I967) with radioactive arginine. Males $\mathrm{n}^{0} \mathrm{I}-3$ received ${ }_{5} 5^{\circ} \mu \mathrm{Ci}$ of $\mathrm{L}$-arginine- $5^{-3} \mathrm{H}$-monohydrochloride, specific activity $500 \mathrm{mCi} / \mathrm{mmol}$ (Amersham), in each testis on day $\mathrm{O} ;$ male $\mathrm{n}^{\circ} 4$ was similarly injected with $25 \mu \mathrm{Ci}$ L-arginine ${ }^{14} \mathrm{C}$ (U), specific activity $\mathbf{I} 60 \mathrm{mCi} / \mathrm{mmol}$ (U. V. V. V. R., Prague), but the injections were repeated once more two days later.

Rabbit $\mathrm{n}^{0} \mathrm{I}$ was hemicastrated after 24 hours and 4 days p.i., and ejaculates were collected from rabbits 2, 3 and 4 twice weekly. Sperm samples were further isolated from the ductus deferens and caudae epididymidis on the day of the last collection (fig. I). Four does were inseminated after HCG injection (IOO IU) with the ejaculate from male $n^{0} 4$, collected on day ${ }^{7} 7$ p.i. Fourteen hours after insemination, these females were slaughtered, and the eggs isolated, mounted on slides, air-dried, and subsequently fixed with acetic alcohol. Histological sections from the testes, and smears of ejaculated and isolated spermatozoa and egg preparations were coated 


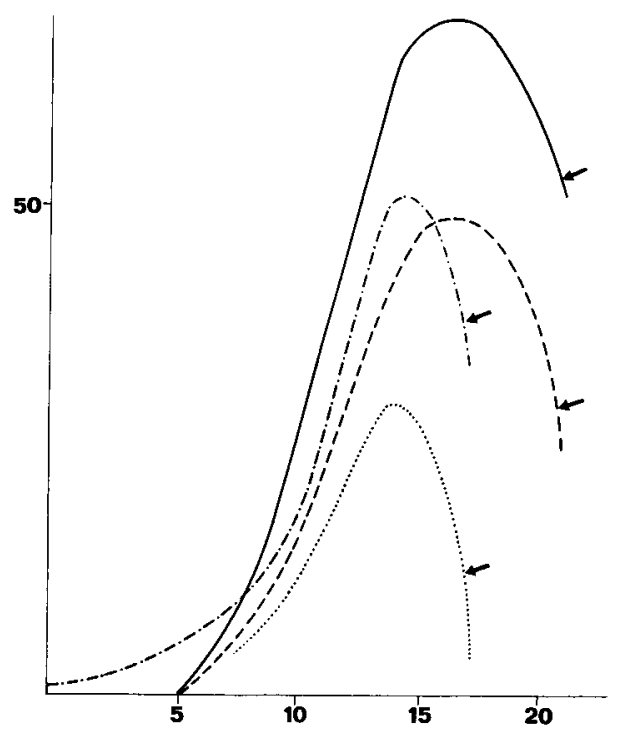

FJG. I. - Availability of labelled rabbit spermatozoa in ejaculates (all curves up to the point marked by an arrow) or in excised ductus deferens and caudae epididymidis (after arrow) following intratesticular injection of ${ }^{3} \mathrm{H}$ - or ${ }^{14} \mathrm{C}$-arginine. Abscissa : days after lst injection. Ordinate : per cent of labelled spermatozoa.

Males $n^{\circ} 2$ and 3 (mean) $\{4$ and more grains/sperm head ${ }^{3} \mathrm{H}$-arginine, injection day o $\quad \ldots \ldots$ Io and more grains/sperm head

Male $n^{0} 4 .{ }^{14} \mathrm{C}$-arginine, $\{-\cdot-\cdots 4$ and more grains/sperm head injections on days $o$ and $2\{\ldots \ldots \ldots . . . . .30$ and more grains/sperms head

Sperm was collected twice weekly. On the day of the last collection (males $\mathbf{n}^{0} 2$ and $3: 2$ Ist day p.i., male $n^{\circ} 4$ : I 7 th day p.i.) ductus deferens, proximal and distal caudae epididymidis were excised and spermatozoa isolated from them, respectively. The labelling data from all cells were included in the graphs.

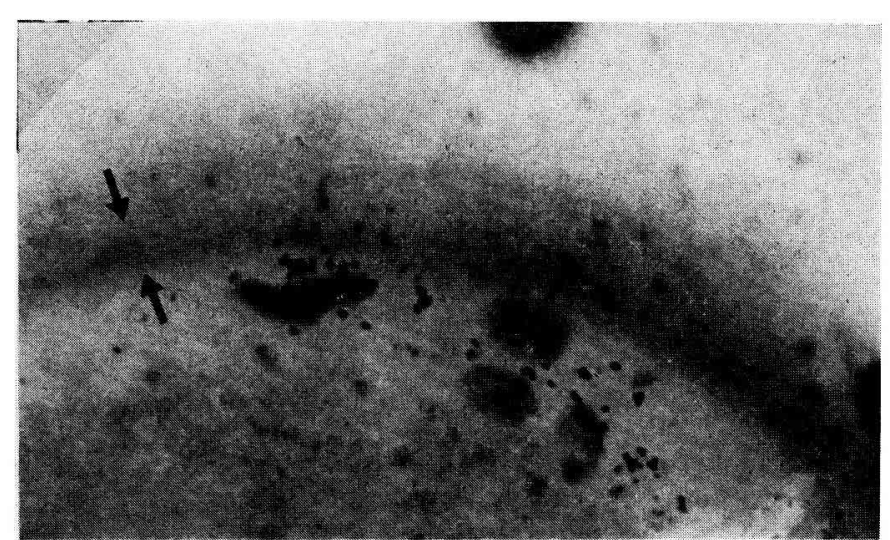

FIG. 2. - Autoradiogram of supplementary rabbit spermatozoa, labelled with ${ }^{14}$ C-arginine, in perivitelline space of a fertilized oocyte

Thick layer of nuclear emulsion Ilford $\mathrm{K}_{5}$, exposure $\mathrm{I}$ I9 days.

Most of length of the ${ }^{14} \mathrm{C}$-tracks originating in spermatozoa is out of focus.

Between arrows : zona pellucida 
with nuclear emulsion Ilford $\mathrm{K}_{5}$ and exposed for varying lengths of time. The oocyte preparations were exposed for I I 9 days and stained with toluidine blue (Gurr) at $\mathrm{pH} 4$ after development.

Intensive labelling was found in elongating spermatid nuclei in testis. A wave of cells in ejaculated spermatozoa showed intensive nuclear labelling with a peak at about 15 days p.i. (fig. I). In fourteen fertilized oocytes (two pronuclei) many supplementary spermatozoa were observed to be the origin of carbon-I 4 tracks (fig. 2). No label was found in early pronuclei.

As observed in this material, the arginine- ${ }^{3} \mathrm{H}$ incorporation in elongation rabbit spermatids probably parellels a similar situation in mouse (Monesi, I964, 1965) and in ram (LoIR, I972 a); it may be considered as localization of the synthesis of basic nuclear arginine-rich spermatozoan protein in these cells. Although repeated intraperitoneal injections in the mouse lead to general spermatozoal labelling (КоРеČNÝ and РАVLOK, I975), sufficient labelling of ejaculate spermatozoa is not achieved by introducing the precursor into the testis via one or two successive intratesticular injections in the rabbit. Thus, total absence of the label in early pronuclei in rabbit cannot be interpreted as a change in nuclear spermatozoal protein during fertilization. On the other hand, the presence of supplementary labelled spermatozoa in the perivitelline space is convincing proof for retention of most of the basic nuclear protein in situ, even after the spermatozoa have undergone capacitation and acrosomal reaction in the female genital tract and penetrated through the zona pellucida. This confirms that the spermatozoal basic nuclear protein of mammals, rich in arginine and synthesized in elongating spermatids, is stable during the independent life of mammalian sperm and does not undergo the transformations observed in some non-mammalian species (MONESI, I97I). The quantitative change in this protein is detectable only during sperm head swelling in the ooplasm (KоPEČN $\breve{Y}$ and PAVLOK, 1975). Retention of the label in spermatozoa does not relate, of course, to possible biochemical modifications of spermatozoan basic protein, which would not affect its arginine content.

Reç pour publication en septembre 1974.

\title{
RÉSUMÉ
}

\author{
LA RÉTENTION DE L'ARGININE- ${ }^{14} \mathrm{C}$ \\ DES NUCLÉOPROTÉINES DES SPERMATOZOÏDES DE LAPIN \\ JUSQU'A LA PÉNÉTRATION DANS LE VITELLUS
}

Le marquage par l'arginine- ${ }^{14} \mathrm{C}$ des nucléoprotéines des spermatozoïdes de Lapin au cours de la spermiogenèse, permet de suivre leur évolution jusqu'à la fécondation.

Aucune modification ne se produit pendant le séjour dans les voies génitales femelles, la capacitation et le franchissement de la membrane pellucide. L'absence de radioactivité dans le pronucleus mâle au début de sa formation laisse penser que ces nucléoprotéines se transforment dès la pénétration du spermatozoïde dans le cytoplasme de l'ovocyte, comme les auteurs l'ont montré d'une manière indiscutable chez la Souris.

\section{REFERENCES}

Chang M.-C., 1959. Fertilizing capacity of spermatozoa. In : Recent progress in the endocrinology of reproduction, p. I53, C. W. Lloyd Ed. Academic Press, New York.

Fulka J., KOPEčni V., KoEfoed-Johnsen H.-H., I967. Labelling of germ cells in the rabbit following intratesticular injection of small doses of thymidine- ${ }^{3} \mathrm{H}$. Aarsheretning Inst. f. Sterilitetsforskn. Copenhagen, 10, 31-36.

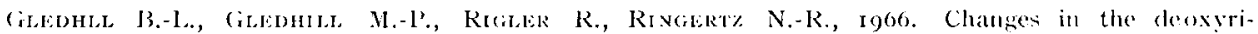
bonucleoprotein during spermiogenesis in the bull. Fixp. (iell Rex., 41, 632-665. 
Kope ČN $\dot{Y}$ V., I970. Labelling of mouse spermatozoa with L-arginine- ${ }^{14} \mathrm{C}$ (U) monohydrochloride. $Z$. Zellforsch., 109, 4I4-4I9.

Kopečný V., PAVLoK A., I975. Autoradiographic study of mouse arginine-rich spermatozoan nuclear protein in fertilization. J. Exptl. Zool., 191, 85-96.

Loir M., i $972 a$. Métabolisme de l'acide ribonucléique et des protéines dans les spermatocytes et les spermatides du bélier (Ovis aries). II. Variation de l'incorporation et devenir de la ${ }^{3} \mathrm{H}$-lysine, de la ${ }^{3} \mathrm{H}$-arginine et de la ${ }^{3} \mathrm{~S}$-cystine. Ann. Biol. anim. Bioch. Biophys., 12, 411-429.

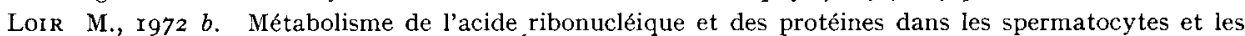
spermatides du bélier (Ovis aries). III. Étude cytochimique des transformations protéiques dans les vieilles spermatides. Ann. Biol. anim. Bioch. Biophys., 12, 53I-544.

Monesi V., I964. Autoradiographic evidence of a nuclear histone synthesis during Mouse spermiogenesis in the absence of detectable quantities of nuclear ribonucleic acid. Exp. Cell Res., 36, 683-688.

Monesi V., r965. Synthetic activities during spermatogenesis in the Mouse : RNA and protein. Exp. Cell Res., 39, I97-224.

Monesi V., I971. Chromosome activities during meiosis and spermiogenesis. J. Reprod. Fert., Suppl. I3, I-I4.

Orgebin-Crist M.-C., 1969. Studies on the function of the epididymis. Biol. Reprod., Suppl. I, I 55-175. 